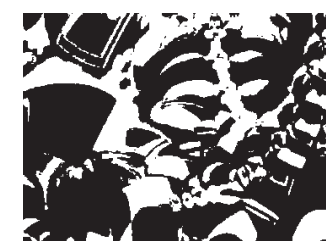

\title{
PREDICTORS OF EARLY RETIREMENT INTENTIONS IN CROATIA
}

Marijana BAĐUN

Institute of Public Finance, Zagreb

Šime SMOLIĆ

Faculty of Economics and Business, Zagreb

UDK: 364.35-642-053(497.5)

Izvorni znanstveni rad

Primljeno: 22. 12. 2017

In this paper, we use the SHARE (Survey of Health, Ageing and Retirement in Europe) Wave 6 dataset to look into the socio-demographic, health, well-being, financial and work-related predictors of intended early retirement in Croatia. We estimate logit regression models. Based on our research, early retirement seems to be more appealing to people who work in the private sector, who have poor quality of life, who are less educated, or report poor health status. Amending the pension system in terms of making early retirement a less attractive choice is not enough. Many Croatian employees would be ready to work longer if they had better jobs, education, and health. These are the policy areas where Croatia needs large improvements.

Keywords: early retirement, pension system, ageing, Croatia, SHARE

$\triangle$ Marijana Bađun, Institute of Public Finance, Smičiklasova 21, 10000 Zagreb, Croatia.

E-mail: marijana.badjun@iif.hr

\section{INTRODUCTION}

More than one out of four old-age pension (OAP) beneficiaries in Croatia entered early retirement (HZMO, 2016). ${ }^{1}$ The share of early old-age pension (EOAP) beneficiaries has been steadily increasing. This was especially pronounced during the 2009-2014 economic crisis. At the same time, the employment rate of workers aged 55-64 in Croatia is the second lowest (following Greece) in the European Union. In 2016, it stood at 38\%, whereas the EU average was 55\% (Eurostat, 2017). The 
DRUŠ. ISTRAŽ. ZAGREB GOD. 27 (2018), BR. 4, STR. $671-690$

BAĐUN, M., SMOLIĆ, Š. PREDICTORS OF EARLY...
European Commission (2018) has been continuously emphasizing the need to take measure to discourage early retirement in Croatia.

The entitlement to the EOAP for men in Croatia is acquired with 60 years of age and 35 years of the qualifying period. In 2017 , women could obtain the right to the EOAP with 56 years and nine months of age (in addition to 31 years and nine months of the completed qualifying period), whereas the age and qualifying period requirements will increase by three months each year until 2030 (60 years of age). From 2031 to 2037, the age limit will be extended by three months each year for both men and women. Starting from 2038, the right to the EOAP will be obtained with 62 years of age (and required qualifying period), regardless of sex.

The EOAP benefit decreases for each month of retirement before the old age limit ( 65 for men and 61 years and 9 months for women in 2017). The deduction ranges from $0.1 \%$ to $0.34 \%$ per month depending on the completed qualifying period. Starting from 2015, the EOAP without deductions is authorized to insurees with 60 years of age and 41 years of the qualifying period. The same goes for an insuree, who, after the termination of his/her insurance because of bankruptcy that took place before the conditions for an EAOP are met, stays registered with the employment agency for at least two continuous years.

Apart from EOAPs, another pathway to early retirement in Croatia are disability pensions. A disability pension can be acquired if an insured person has one of two potential types of disability: occupational or general incapacity for work, along with a completed qualifying period. The former is considered total disability and the latter partial. Nearly one quarter of Croatia's retired population is receiving a pension based on disability, which is higher than the EU average, even without taking into account war veterans (Bađun, 2017). When adding EOA and disability pensioners, we find that $39 \%$ of all pensioners entered early retirement. The average age of pensioners who entered early old-age retirement in 2016 was 59.2, whereas the average age for disability and old-age pensioners was 53.8 and 63.8, respectively (HZMO, 2016). Apart from war veterans, there are several other groups entitled to pensions under more favorable conditions (special regulations), i.e. to an earlier exit from the labor market.

Many European countries have stimulated different models of early exit from the labor force, with principal instruments being unemployment insurance, prolonged access to sickness and disability benefits, or development of particular pre-retirement programs (Van Bavel \& De Winter, 2013). Higher national wealth correlates with a lower probability of early retirement, whereas an increasing unemployment rate gener- 
DRUŠ. ISTRAŽ. ZAGREB GOD. 27 (2018), BR. 4 STR. $671-690$

BAĐUN, M., SMOLIĆ, Š. PREDICTORS OF EARLY... ates more early retirement (Fischer \& Sousa-Poza, 2006). Countries dealing with economic recessions and having strict employment protection legislation tend to push individuals towards 'involuntary' retirement (Dorn \& Sousa-Poza, 2010).

Even though 'involuntary' retirement is an outcome of a worker's rational choice, the choice is limited by the lack of employment options. This is usually accompanied by general early retirement provisions that make 'involuntary' early retirement more appealing. Employers may also push workers to retire early with additional compensation. The explanation for large shares of 'involuntary' early retirement in Eastern European countries (namely Hungary, Slovenia and Poland) was found in their industrial restructuring and economic transition (Dorn \& Sousa-Poza, 2010). In the 1990s, the costs of transition were shifted to the pension system through mass early retirement (Polanec, Ahčan, \& Verbič, 2013), which was the case in Croatia as well (Vehovec, 2003; Rutkowski, 2007). Many elderly workers who lost their jobs and lacked skills to find new ones withdrew from the labor force through early retirement.

The decision to stop working before the legal retirement age (around 65 in most developed countries) is affected by an array of factors. The importance of institutional and macroeconomic factors in the large number of early retirees in Croatia was recognized by Rutkowski (2007), Nestić and Rašić Bakarić (2008), Baloković (2011), Vukorepa (2015) and Bađun (2017). In sum, the design of the Croatian pension system (low statutory retirement age, lax rules governing eligibility for disability pensions, relatively weak penalties for early retirement and hence relatively small differences in pension benefits between early and regular retirement, special pension regulations for various groups) has strongly affected the low employment rate among older workers. ${ }^{2}$

In this paper, we use the 'Survey of Health, Ageing and Retirement in Europe' (SHARE) Wave 6 data to look into the socio-demographic, health, well-being, financial and work-related predictors of intended early retirement in Croatia. We try to go beyond the institutional setting and look into retirement intentions of the employed population, men aged 50-64 and women aged 50-61. This is the first attempt to use individual-level data in order to analyze retirement issues in Croatia.

\section{PREDICTORS OF EARLY RETIREMENT: PREVIOUS RESEARCH}

Exit from the labor market before OAP is affected by so-called push and pull factors (van den Berg, Elders, \& Burdorf, 2010). Pull factors are positive considerations and boost an employee's interest in early retirement, whereas push factors are negative issues which encourage people toward early exits. There is vast literature that examines a great number of push and pull factors, but they can be broadly summarized in five groups: 
DRUŠ. ISTRAŽ. ZAGREB GOD. 27 (2018), BR. 4, STR. $671-690$

BAĐUN, M., SMOLIĆ, Š.: PREDICTORS OF EARLY.. institutional, health-related, work-related, socio-demographic and financial factors.

The availability of institutional early retirement options most probably functions as a pull factor; labor inactivity among the elderly is likely to be particularly high in countries in which early retirement programs have been heavily advocated (Gómez-Léon \& Miret-Gamudi, 2014). On the other hand, making early retirement less generous and rewarding individuals for postponing retirement induces workers to delay retirement (Euwals, van Vuuren, \& Wolthoff, 2010).

Institutional changes also have spillover effects. For example, two pension reforms that increased the early retirement age in Austria increased employment among high-wage and healthy workers, whereas low-wage and less healthy workers went on retiring early via disability benefits or overpassed the gap to the early retirement age via unemployment benefits (Staubli \& Zweimüller, 2013). Likewise, a Dutch policy reform that introduced job-search requirements in unemployment insurance (UI) for persons aged 57.5+ discouraged older people from entering unemployment; the probability of self-employment as an exit route to retirement increased relative to UI, but not relative to paid-employment (Been \& Knoef, 2017). If there are incentives to retire fully at relatively young ages, even the scope for gradual retirement (various paths out of the labor force where individuals do not leave their jobs abruptly, but in a stepwise fashion) is limited (Bloemen, Hochguertel, \& Zweerink, 2016).

De Wind et al. (2013) explain that poor health, a push factor, can influence early retirement because employees are: a) unable to work, b) believe their ability to work will decline in the future, c) are afraid that their health will deteriorate further or d) feel pushed out by their employer, even though they do not experience reduced working ability. They furthermore show that good health also influences early retirement because people want to enjoy life while their health still allows them.

Many studies confirm that poor health is a strong predictor of early retirement (e.g. Bonsdorff, Huuhtanen, Tuomi, \& Seitsamo, 2010; Dwyer \& Mitchell, 1999; van den Berg et al., 2010, etc.). This holds for both objective health measures and self-rated health (SRH). In addition, specific diseases bear a higher risk of early retirement. This has, for example, been shown for depression (Karpansalo et al., 2005), diabetes (Vijan, Hayward, \& Langa, 2004), cancer (Carlsen, Oksbjerg Dalton, Frederiksen, Diderichsen, \& Johansen, 2008), circulatory disorders (Dwyer \& Mitchell, 1999). Functional limitations in activities of daily living (ADLs) and instrumental activities of daily living (IADLs) also result in earlier expected retirement (Dwyer \& Mitchell, 1999). 
DRUŠ. ISTRAŽ. ZAGREB GOD. 27 (2018), BR. 4 STR. $671-690$

BAĐUN, M., SMOLIĆ, Š. PREDICTORS OF EARLY...
Various dimensions of work quality strongly correlate with early retirement (Bonsdorff et al., 2010; Dal Bianco, Trevisan, \& Weber, 2015; Lund \& Villadsen, 2005; Siegrist, Wahrendorf, von dem Knesebeck, Jürges, \& Börsch-Supan, 2007; van den Berg et al., 2010). The type of work is also an important factor (Dorn \& Sousa-Poza, 2005). Furthermore, Schils (2008) notes that self-employed individuals might have higher preference for work and might face lower early retirement probabilities as compared to employees in more sheltered sectors, e.g. the public sector. It is important to mention that unemployment is also a factor that pushes people towards early retirement (Bould, 1980).

Many socio-demographic characteristics likewise influence the decision to retire. Early retirement is usually associated with increasing age because entitlement to early retirement programs is more likely, but there are exceptions (see e.g. Bonsdorff et al., 2010). Highly educated individuals are less likely to retire early (Gómez-Léon \& Miret-Gamudi, 2014; Siegrist et al., 2007). Retirement intentions are also gender-dependent, with mixed evidence (Bonsdorff et al., 2010; Dahl, Nilsen, \& Vaage, 2003). The same holds for marital status and characteristics (see e.g. van den Berg et al., 2010; Bonsdorff et al., 2010; Dahl et al., 2003; Danø, Ejrnæs \& Husted, 2005). Furthermore, it seems that entering retirement is a joint decision made by couples (Szinovacz \& Deviney, 2000; de Wind et al., 2014), not only individuals. Interestingly, it is also influenced by marital satisfaction: spouses living in unhappy marriages tend to postpone retirement (Kubicek, Korunka, Hoonakker, \& Raymo, 2010). Becoming a grandparent speeds up retirement (Hochman \& Lewin-Epstein, 2013) and the effect has been found stronger for women by Van Bavel \& De Winter (2013) but not by the previously mentioned authors.

Lower socio-economic position increases the odds for early retirement (Lund \& Villadsen, 2005). On the other hand, de Wind et al. (2014) find that in the Netherlands the financial possibility to stop working before the age of 65 predicts early retirement. Hochman \& Lewin-Epstein (2013) believe that economic factors are not significant in retirement preferences, but are in actual retirement decisions. Finally, Fischer \& Sousa-Poza (2006) have found that the influence of pension wealth accrual on early retirement is stronger than the gross replacement rate. What matters is the opportunity cost of retiring early.

\section{DATA AND METHODS}

We investigate the early retirement intentions (ERI) of employed Croatians, using the SHARE Wave 6 database. ${ }^{3}$ SHARE is a multinational and multidisciplinary panel database of micro data on health and well-being, socioeconomic status and social and family networks of the population aged $50+$. 
DRUŠ. ISTRAŽ. ZAGREB GOD. 27 (2018), BR. 4, STR. $671-690$

BAĐUN, M., SMOLIĆ, Š.: PREDICTORS OF EARLY...
It is modelled on the Health and Retirement Study (HRS) and the English Longitudinal Study of Ageing (ELSA), which are similar longitudinal surveys in the United States and England. SHARE Wave 6 database contains more than 68,000 face-to-face interviews collected in 18 countries in 2015 (Börsch-Supan, 2017). ${ }^{4}$ Croatian participation in SHARE started in Wave 6. Data collection took place from June to November 2015, resulting in 2,494 individual interviews. SHARE data collection is based on computer-assisted personal interviewing (CAPI). The SHARE target population consists of all persons aged $50+$ at the time of sampling who have their regular domicile in the respective SHARE country. In Wave 6, all household members born 1964 or earlier were eligible for an interview, whereas current partners living in the same household were interviewed regardless of their age (Börsch-Supan, 2017).

We too support the finding that the intention to retire is a strong indicator of the actual event of retirement, and usually precedes the decision to withdraw permanently from employment (Bonsdorff et al., 2010). The outcome variable ERI has been assessed using the following question: 'Thinking about your present job, would you like to retire as early as you can from this (main) job?'. In the full cross-sectional sample of 2,494 respondents included, 493 respondents reported themselves as working, 1,411 as retired, 232 as homemaker, 213 were unemployed, 40 of them were permanently sick or disabled, and for 105 the reported current job situation was 'other' or unknown. In the next step, we restricted the sample to employed or self-employed men aged 50-64 and women aged 50-61, i.e. below the statutory retirement age. After exclusion of sporadically missing values for other variables, 432 observations were included in the analysis.

In accordance with previous empirical results, we chose a set of covariates for the analysis. Age was calculated by deducting interview month and year from month and year of birth, and three age groups account for possible age-specific differences. Education level was measured according to International Standard Classification of Education (ISCED-97), and categorized into low (ISCED 0-2), medium (ISCED 3-4) and high (ISCED 5-6) education. Furthermore, dummies for gender and marital status were created taking value 1 if respondent is female and married and living with a spouse. A dummy variable was used to indicate if the respondent looked after grandchildren without the presence of the parents.

Self-rated health (SRH) was measured by a single question (US version of SRH where self-reported general health status is measured using a scale ranging from 1 for Excellent to 5 for Poor), and five answer options were dichotomized into 'less than very good', and 'very good and excellent'. SRH is a very 
DRUŠ. ISTRAŽ. ZAGREB GOD. 27 (2018), BR. 4 STR. $671-690$

BAĐUN, M., SMOLIĆ, Š.: PREDICTORS OF EARLY...

(1) TABLE 1

Variables used in empirical analysis informative measure of health status (Idler \& Benyamini, 1997), and is widely used as a predictor of morbidity, disability or mortality among the elderly (see e.g. Jylhä, 2009). Respondents were asked about chronic diseases, and we used a dichotomous variable indicating two or more chronic diseases. The CASP-12 scale was used to measure quality of life (QoL). The so-called CASP-12 measure is comprised of 12 Likert-type questions grouped in four dimensions that reflect QoL Control, Autonomy, Self-realization and Pleasure. We used CASP index ranging from 12 to 48 where a higher score indicates better QoL, and followed the strategy presented by Siegrist et al. (2007), who defined participants in the lowest tercile as those having poor QoL.

In SHARE Wave 6, respondents who participated in the previous SHARE waves answered a battery of questions related to work quality. However, respondents in Croatia who participated in the SHARE for the first time did not answer these questions. Nevertheless, we could employ other work-related variables, i.e. we use a dummy for private sector employee and self-employed, as well as the type of contract. Financial situation is obtained by summarizing all individual income components at the household level. Income is presented in income quintiles, and in cases where income components were missing, it was based on imputation (see De Luca, Celidoni, \& Trevisan, 2015). Variables used in the analysis are presented in Table 1.

Early retirement intentions $(\mathrm{ERI})^{5} \quad 1$ if respondent reported intention to retire as soon as possible from main job, 0 otherwise

Gender 1 if respondent is female, 0 if male

Age Categorical variable with age groups 50-54, 55-59 and 60-64

Married 1 if married and living with spouse, 0 otherwise

Child(ren) 1 if child(ren) aged 0-18 is living in the household Look after grandchildren 1 if respondent looked after grandchildren

Education Categorical variable, value 1 for low, 2 for medium and 3 for high education

Poor SRH 1 if respondent reported less than very good health status

Chronic diseases (good, fair, and poor), 0 otherwise (excellent, very good) 1 if respondent reported 2 or more chronic diseases, 0 otherwise

Poor QoL 1 if respondent is in the lowest tercile, 0 otherwise

Private sector 1 if respondent is private sector employee or self-employed, 0 if public sector employee

Permanent contract 1 if respondent has permanent contract, 0 if short-term Income quintile Categorical variable for adjusted household income quintiles

Note: ERI variable in the SHARE dataset indicates whether the respondent is looking for early retirement if their current job status is 'employed' or 'self-employed'. We defined it as 'before the statutory retirement age'. 
DRUŠ. ISTRAŽ. ZAGREB GOD. 27 (2018), BR. 4, STR. $671-690$

BAĐUN, M., SMOLIĆ, Š.: PREDICTORS OF EARLY..
We use the logit model to estimate the probability of ERI (dichotomous outcome variable). Our goal is to predict the probability of the form $\mathrm{P}(\mathrm{Y}=1 \mid \mathrm{X} 1, \ldots, \mathrm{Xn})$, i.e. we predict the possibility of realization of the outcome variable ( $Y$ with $0 / 1$ outcome) depending on combinations of values of the predictor variables $(X)$. Although regression models were not weighted, we used Huber-White corrections for standard errors to account for clustering at the household level.

\section{RESULTS}

\section{Descriptive findings}

Figure 1 reveals proportions and the mean age of employed persons interviewed in SHARE Wave 6 who intended to retire as soon as possible. We restricted the sample to those aged from 50 to 64, which, according to Siegrist et al. (2007), is considered as an age period with higher chances for an early retirement decision. The highest share of employed individu-

(1) FIGURE 1

Respondents aged 50-64 who intend to retire as soon as possible (in \%), and their mean age (right scale), $n=14,622$ als aged 50-64 with ERI is found for Slovenia, Italy and Poland $(>60 \%)$, and the lowest for Israel, Estonia and Switzerland $(<35 \%)$. Croatia can be placed in the group of countries with the lower share of workers with ERI (36.3\%), their mean age being among the lowest (56 years).

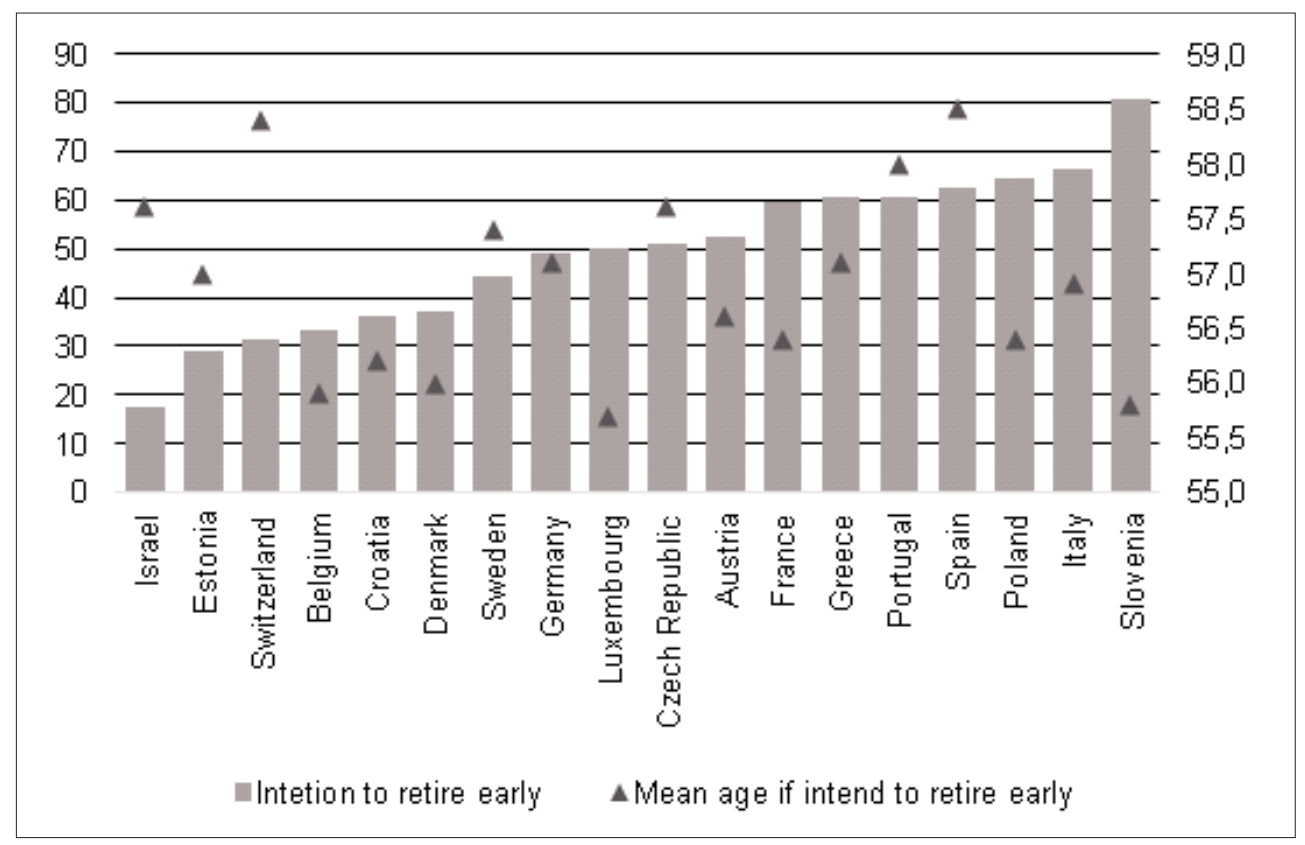

In Table 2 we classify 432 employees according to socio-demographic, health, well-being and work-related characteristics in two distinct groups: those who intend to retire as soon as possible (before the statutory retirement age) and those 
DRUŠ. ISTRAŽ. ZAGREB GOD. 27 (2018), BR. 4 STR. $671-690$

BAĐUN, M., SMOLIĆ, Š. PREDICTORS OF EARLY...

(1) TABLE 2

Descriptive statistics of socio-demographic health, well-being, financial and work-related characteristics who do not intend to retire early. Some 159 respondents or $37 \%$ of the sample reported they would like to retire early. Almost four out of ten respondents with ERI were female, whereas males were more likely to report ERI than females (39\% vs. 34\%, but not presented in Table 2). Almost four in five individuals were married and living with a spouse or partner, but this does not seem to be associated with ERI. One of two respondents was in the age group 55-59, and even though age does not seem to affect ERI, it becomes more probable in the age group 60-64. A statistically significant difference according to ERI was found for the level of education. The probability of ERI decreases with the increase in the level of education. In addition, no statically significant difference according to ERI was detected for respondents who were looking after grandchild(ren) or living with minor child(ren) in the household.

Overall, one of two respondents from the sample reported poor SRH, and there was a significant statistical difference between two groups according to their ERI intentions. One in five individuals reported two or more chronic diseases, and one in four of those who were thinking about early retirement. The pattern is also clear for QoL, i.e. poor QoL is significantly correlated with ERI.

\begin{tabular}{|c|c|c|c|c|c|}
\hline & & $\begin{array}{r}\text { All } \\
\text { respondents } \\
(n=432)\end{array}$ & $\begin{array}{r}\text { Intend } \\
\text { to retire early } \\
(n=159)\end{array}$ & $\begin{array}{r}\text { Do not intend } \\
\text { to retire early } \\
(n=273)\end{array}$ & Significance \\
\hline Gender & Female & 40.4 & 37.3 & 42.3 & ns \\
\hline \multirow[t]{3}{*}{ Age } & $50-54$ & 38.8 & 38.2 & 38.9 & ns \\
\hline & $55-59$ & 46.5 & 45.2 & 47.6 & \\
\hline & $60-64$ & 14.7 & 16.6 & 13.5 & \\
\hline Married & & 80.2 & 80.5 & 80.1 & ns \\
\hline Child(ren) & & 9.8 & 10.4 & 9.4 & ns \\
\hline Look after grandchildren & & 17.1 & 19.3 & 15.7 & ns \\
\hline \multirow[t]{3}{*}{ Education } & Low & 34.5 & 45.0 & 28.3 & $* * *$ \\
\hline & Medium & 40.6 & 39.6 & 41.2 & \\
\hline & High & 24.9 & 15.4 & 30.6 & \\
\hline Poor SRH & & 51.4 & 60.9 & 45.8 & ** \\
\hline Chronic diseases & & 22.0 & 25.2 & 20.0 & ns \\
\hline Poor QoL & & 36.6 & 44.3 & 32.0 & $* *$ \\
\hline Private sector & & 57.9 & 66.9 & 52.8 & ** \\
\hline Permanent contract & & 87.9 & 85.9 & 89.1 & * \\
\hline \multirow[t]{5}{*}{ Income quintile } & 1st & 27.4 & 26.6 & 27.8 & ns \\
\hline & 2nd & 9.5 & 11.5 & 8.6 & \\
\hline & $3 r d$ & 11.1 & 13.0 & 10.0 & \\
\hline & 4 th & 17.5 & 16.2 & 18.4 & \\
\hline & 5 th & 34.5 & 32.7 & 35.3 & \\
\hline
\end{tabular}

Note: descriptive statistics deployed above are computed using individual weights, totals $(n)$ are unweighted, ns: not significant, ${ }^{*} p<0.1,{ }^{* *} p<0.05,{ }^{* * *} p<0.001$, aWilcoxon rank-sum test. 
DRUŠ. ISTRAŽ. ZAGREB GOD. 27 (2018), BR. 4, STR. $671-690$

BAĐUN, M., SMOLIĆ, Š. PREDICTORS OF EARLY..
Respondents in the private sector account for $67 \%$ of those who intend to retire early from their main job, and 53\% of those who do not. There is also a statistically significant difference between the two groups according to the variable indicating the sector of employment. Of the respondents in the ERI group, a slightly lower proportion (86\%) have a permanent employment contract compared to the reference group (89\%). Finally, one of three respondents who intend to retire early is in the highest income quintile, similar to the reference group. For the income variable, we could not find a significant difference between the two groups.

\section{Inferential findings}

Table 3 summarizes estimated coefficients of the binary logistic regression. The results are presented in three separate models. In the first model, the analysis is restricted to socio-demographic variables, and only the variable education is statistically significant. The education variable has a negative coefficient indicating that respondents with a higher level of education are less likely to report ERI. We can observe that respondents who have a higher level of education, compared to the reference category (low education), have a 37\% lower probability to report ERI. The rest of the variables in this model were statistically insignificant.

In model II, three variables of well-being were introduced. Variables poor SRH status and poor QoL both have positive coefficients, as we expected, and are statistically significant. Respondents who reported poor health status or have poor QoL have a higher probability of thinking about early retirement, $62 \%$ and $63 \%$ respectively. The coefficient of the variable chronic diseases has a negative sign, i.e. individuals with two or more chronic diseases tend to think less about early retirement compared to the reference group, although the relationship is insignificant. This finding is in line with that of Miah \& Wilcox-Gök (2011) who explained this with lower asset accumulation of individuals with chronic illness.

The third, final model included variables for the sector of employment, type of contract and income quintile of respondents. Variables for education, poor SRH and poor QoL remained statistically significant with the expected signs of the variable coefficients. If we set the covariates at their mean, we can say, e.g. that a hypothetical employee with poor SRH who intends to retire as soon as possible and who is average in all the other covariates, will have a 13\% higher probability of ERI than a hypothetical employee with very good or excellent SRH. Equally, we can say that employees with poor QoL who are average on covariates, are $11 \%$ more likely to report ERI than respondents in the second or third CASP tercile. In addi- 
DRUŠ. ISTRAŽ. ZAGREB GOD. 27 (2018), BR. 4 STR. $671-690$

BAĐUN, M., SMOLIĆ, Š.: PREDICTORS OF EARLY...

(1) TABLE 3

Logit marginal effects on the probability of early retirement intentions $(n=432)$ tion, we can see that employees in the private sector and the self-employed have a statistically significant and higher probability (about 64\%), or nearly 1.8 times greater odds of thinking about retreating from their current job. Having a permanent employment contract, and thus better job security, lowers the probability of reporting ERI, but we could not obtain statistically significant evidence on this. Furthermore, the higher the income quintile the respondent belongs to, the higher the probability of reporting ERI.

\begin{tabular}{|c|c|c|c|}
\hline \multirow[b]{2}{*}{ Variables } & \multicolumn{3}{|r|}{ Model } \\
\hline & I & II & $\overline{\text { III }}$ \\
\hline Gender & $\begin{array}{l}-0.027 \\
(0.210)\end{array}$ & $\begin{array}{l}-0.106 \\
(0.217)\end{array}$ & $\begin{array}{l}-0.108 \\
(0.221)\end{array}$ \\
\hline Age & $\begin{array}{c}0.014 \\
(0.163)\end{array}$ & $\begin{array}{c}0.028 \\
(0.165)\end{array}$ & $\begin{array}{c}0.016 \\
(0.167)\end{array}$ \\
\hline Married & $\begin{array}{l}-0.081 \\
(0.301)\end{array}$ & $\begin{array}{l}-0.084 \\
(0.306)\end{array}$ & $\begin{array}{l}-0.111 \\
(0.312)\end{array}$ \\
\hline Child(ren) & $\begin{array}{c}0.117 \\
(0.397)\end{array}$ & $\begin{array}{c}0.168 \\
(0.401)\end{array}$ & $\begin{array}{c}0.136 \\
(0.411)\end{array}$ \\
\hline Look after grandchildren & $\begin{array}{c}0.253 \\
(0.274)\end{array}$ & $\begin{array}{c}0.255 \\
(0.278)\end{array}$ & $\begin{array}{c}0.279 \\
(0.279)\end{array}$ \\
\hline Education & $\begin{array}{l}-0.536^{* * *} \\
(0.147)\end{array}$ & $\begin{array}{l}-0.471^{* *} \\
(0.149)\end{array}$ & $\begin{array}{l}-0.429^{* *} \\
(0.152)\end{array}$ \\
\hline Poor SRH & & $\begin{array}{l}0.478^{* *} \\
(0.234)\end{array}$ & $\begin{array}{l}0.552^{* *} \\
(0.242)\end{array}$ \\
\hline Chronic diseases & & $\begin{array}{l}-0.009 \\
(0.111)\end{array}$ & $\begin{array}{c}0.027 \\
(0.111)\end{array}$ \\
\hline Poor QoL & & $\begin{array}{c}0.520^{* *} \\
(0.221)\end{array}$ & $\begin{array}{l}0.464^{* *} \\
(0.221)\end{array}$ \\
\hline Private sector & & & $\begin{array}{l}0.566^{* *} \\
(0.234)\end{array}$ \\
\hline Permanent contract & & & $\begin{array}{l}-0.411 \\
(0.344)\end{array}$ \\
\hline Income quintile & & & $\begin{array}{c}0.027 \\
(0.071)\end{array}$ \\
\hline Mc. Faddens Adj. $R^{2}$ & 0.030 & 0.052 & 0.067 \\
\hline
\end{tabular}

${ }^{* * *} p<0.001,{ }^{* *} p<0.05$, standard errors in parentheses

\section{DISCUSSION}

Our findings regarding early retirement predictors in Croatia are similar to international evidence. However, gender, marital status and income are not statistically significant. The main weakness of our research is a relatively small sample size, which reflects the low employment rate of the observed pop- 
DRUŠ. ISTRAŽ. ZAGREB GOD. 27 (2018), BR. 4, STR. $671-690$

BAĐUN, M., SMOLIĆ, Š.: PREDICTORS OF EARLY.. ulation. In addition, insufficient attention is given to work-related factors due to SHARE data unavailability. Our result that individuals working in the private sector are two times more likely to think about early retirement as compared to those whose main job is in the public sector, points to a divide between Croatia's public and private sector. Nestić, Rubil, and Tomić (2015) have shown that employees in the public sector, whose share in total employment was around 40\% in 2012, are, on average, better educated and better paid. Public sector comprises employees in the sectors of health, education, public administration and in government-owned companies, except in previously mentioned sectors, whereas the rest are private sector employees. In 2012, the share of employees older than 50 was $46 \%$ in the public sector and less than $30 \%$ in the private sector.

It is important to mention that in Croatia, because of the application of the minimum pension, net replacement rate increases with age/career length but falls with earnings (Nestić \& Rašić Bakarić, 2008). Hence, retirement means a bigger relative loss of income to high-wage than to low-wage workers. In other words, early retirement should be more attractive to low-wage workers but in our analysis income was not a statistically significant variable. As already pointed out by Nestić \& Rašić Bakarić (2008), workers could find their future pension benefit too low in cases of both early and regular retirement (since the difference is relatively small) and therefore are not motivated to stay in regular employment after becoming entitled to an EOAP. According to a survey carried out in Croatia in 2015, one third of Croatians believe that retired individuals are most likely to work on an undeclared basis compared with other employment statuses (Franic \& Williams, 2017). It can be a neat way of combining income security by receiving a pension and earning opportunities by taking casual jobs.

Work quality also matters. Based on the Fifth European Working Conditions Survey (EWCS) carried out in 2010, Šverko \& Galić (2014) find that CEE countries lag behind Western European countries in the perceived quality of working life (QWL), especially in economic security. This aspect of QWL has been shown to be the key work life predictor of 'general' life satisfaction (Drobnič, Beham, \& Präg, 2010). Results for Croatia are similar to those of other transition countries, although with relatively high ratings for social relations at work. Other components of QWL considered by Šverko \& Galić (2014) are meaningfulness of work and autonomy and participation in decision-making. Unfortunately, it seems that in terms of job quality, based on EWCS 2015 data, Croatia again lags behind other transition economies. In Croatia, 32\% 
DRUŠ. ISTRAŽ. ZAGREB GOD. 27 (2018), BR. 4 STR. $671-690$

BAĐUN, M., SMOLIĆ, Š. PREDICTORS OF EARLY... of workers had jobs of poor quality, whereas the EU28 average was $20 \%$. At the same time, only $8 \%$ of workers had 'high flying' jobs, compared to the EU28 average of $21 \%$ (Eurofound, 2017). It is highly probable that older workers are even worse off in terms of job quality.

In a recent study, Ameriks et al. (2017) showed that older Americans have a strong desire to work, even those who have long been retired. The authors concluded that demand-side factors play a very important role in explaining the late-in-life labor market; older citizens would like to work longer if there were acceptable job opportunities, especially jobs with a flexible schedule and with similar characteristics to the last job they had. They would even be willing to take a significant wage reduction if such an opportunity occurred. However, employers do not find it profitable to hire older workers on part-time schedules.

Eurobarometer data show that one third of Europeans currently in work would like to continue working after they become entitled to a pension (European Commission, 2011). In addition, the older they get, the more likely they would be willing to continue working longer. According to the EWCS carried out in 2015 (Eurofound, 2017), the share of participants aged 56+ who felt they could do their job in five years' time in Croatia was similar to the EU28 average (around 70\%). Interestingly, in Croatia the percentage of women who declared they would be able to do their job in five years' time was higher than the percentage of men, whereas the opposite holds for the EU28 average.

The main reason why individuals aged $50+$ in the SHARE Wave 6 participating countries retired is the fact that they became eligible for a pension, either public or private (see Table 1 in the Appendix). However, two countries stand out: Croatia and Denmark. Only approximately half of the respondents in these countries retired because they became eligible. Almost 19\% of all respondents in Croatia retired because they were 'offered an early retirement option/window with special incentives or bonus', which is the highest share among all participating countries. This confirms that Croatia too is among countries where 'involuntary' retirement is widespread. Another equally important reason for retirement in Croatia was ill health (20\% of respondents), whereas only Austria and Portugal had a higher percentage in this category. In case of Denmark, around $30 \%$ of respondents retired because they wanted to enjoy life. The same motive was also strong in Sweden (22\%) and Switzerland $(16 \%)$, whereas on average it had a small role in other countries. In Croatia, only $1 \%$ of the respondents retired because they wanted to enjoy life. 
Based on our research, early retirement in Croatia seems to be perceived as a shelter for people who work in tougher working conditions with lower economic security (private sector), who have poor QoL, are less educated (hence also, on average, have worse working life quality) or report poor health status. Amending the pension system by making early retirement a less attractive choice is not enough. Many Croatian employees would be ready to work longer if they had better jobs, better education, better health, and better QoL. These are the policy areas where Croatia needs large improvements, and SHARE could help us deliver evidence for reforms that will extend working life. It would be extremely valuable to link SHARE data with administrative data, i.e. the Croatian Pension Insurance Institute database.

Policy makers must recognize heterogeneity among older workers when implementing further reforms. Furthermore, although individual factors are indeed important, policy makers should take into account that entering early retirement in Croatia is often caused by poor economic restructuring. Decreasing early pension amounts even further can seem as an undeserved punishment.

\section{ACKNOWLEDGEMENTS AND FUNDING}

The SHARE data collection has been primarily funded by the European Commission through FP5 (QLK6-CT-2001-00360), FP6 (SHARE-I3: RII-CT-2006-062193, COMPARE: CIT5-CT-2005-028857, SHARELIFE: CIT4-CT-2006-028812) and FP7 (SHARE-PREP: N²11909, SHARE-LEAP: N²27822, SHARE M4: $\mathrm{N}^{\circ} 261982$ ). Additional funding from the German Ministry of Education and Research, the Max Planck Society for the Advancement of Science, the U.S. National Institute on Aging (U01 AG09740-13S2, P01_AG005842, P01_AG08291, P30_AG12815, R21_AG025169, Y1-ĀG-4553-01, IAG_BSR06-11, OGHA_04-064, HHSN271201300071C) and from various national funding sources is gratefully acknowledged (see https:/www.shareproject.org).

\section{NOTES}

1 At the end of 2016, the share of EOAP beneficiaries in total OAP beneficiaries was $28 \%$. In calculating this share, disability pensions that were, by law, transformed into OAPs in 2015 have not been considered as OAPs.

2 Average OAP benefit in December 2016 was HRK 2,482 (EUR 327) and average EOAP benefit was HRK 2,342 (EUR 308) (HZMO, 2016, p. 11).

3 Release 6.0.0 of 31 March 2017.

${ }^{4}$ See Börsch-Supan et al. (2013) for methodological details, and SHARE Wave 6 documentation for the full list of participating countries. 
DRUŠ. ISTRAŽ. ZAGREB GOD. 27 (2018), BR. 4 STR. $671-690$

BAĐUN, M., SMOLIĆ, Š.: PREDICTORS OF EARLY...
${ }^{5}$ To avoid the self-selection bias we conducted additional analysis by restricting the age of respondents to early retirement conditions in Croatia in 2015, i.e. the year of interviewing in SHARE Wave 6 (56 years and 3 months for females and 60 for males). Our sample size dropped by $27 \%$. However, our conclusions on main predictors remained stable and statistically significant.

\section{APPENDIX}

Main reasons for which individuals aged $\mathbf{5 0 +}$ retired in the SHARE Wave 6 participating countries

\begin{tabular}{|c|c|c|c|c|c|c|c|c|c|c|}
\hline & Reason for retirement/Country & 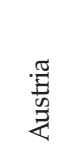 & 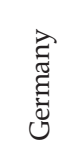 & 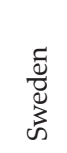 & $\begin{array}{l}\text { है } \\
\text { के }\end{array}$ & 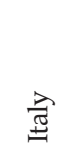 & 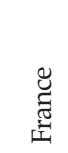 & 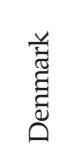 & 苋 & 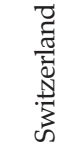 \\
\hline 1. & Became eligible for public pension & 71.9 & 73.6 & 62.4 & 71.8 & 73.5 & 60.1 & 39.3 & 89.1 & 60.0 \\
\hline 2. & Became eligible for private occupational pension & 0.2 & 6.2 & 23.0 & 0.0 & 17.3 & 16.5 & 16.0 & 0.5 & 12.4 \\
\hline 3. & Became eligible for a private pension & 0.0 & 0.7 & 8.3 & 0.0 & 0.3 & 16.9 & 5.6 & 0.2 & 0.5 \\
\hline & $\begin{array}{l}\text { Was offered an early retirement option/window } \\
\text { with special incentives or bonus }\end{array}$ & 1.6 & 10.4 & 8.8 & 15.0 & 3.3 & 8.2 & 13.8 & 2.1 & 8.8 \\
\hline 5. & Made redundant (for example pre-retirement) & 2.3 & 1.5 & 3.2 & 6.4 & 1.2 & 0.7 & 12.0 & 0.2 & 4.5 \\
\hline 6. & Own ill health & 25.0 & 12.7 & 12.2 & 8.3 & 3.3 & 6.0 & 13.9 & 6.3 & 3.4 \\
\hline 7. & Ill health of relative or friend & 0.0 & 1.5 & 0.9 & 0.0 & 0.6 & 2.9 & 0.7 & 0.9 & 0.4 \\
\hline 8. & To retire at same time as spouse or partner & 0.0 & 1.5 & 3.6 & 0.3 & 0.2 & 1.4 & 4.9 & 0.3 & 3.5 \\
\hline 9. & To spend more time with family & 1.0 & 5.0 & 3.7 & 5.0 & 1.3 & 4.5 & 18.8 & 2.5 & 4.1 \\
\hline 10. & To enjoy life & 1.6 & 7.1 & 22.3 & 2.9 & 2.0 & 9.1 & 29.6 & 1.8 & 16.0 \\
\hline & Reason for retirement/Country & 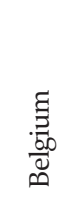 & 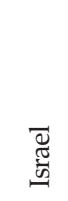 & 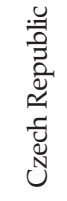 & 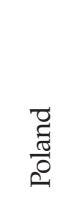 & 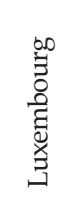 & 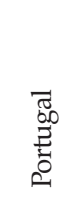 & $\begin{array}{l}\cdot \frac{\pi}{Z} \\
\frac{0}{d} \\
\frac{0}{\omega}\end{array}$ & $\begin{array}{l}\stackrel{0}{J} \\
\stackrel{0}{0} \\
\frac{\mathbb{5}}{4}\end{array}$ & 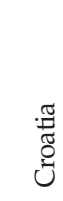 \\
\hline 1. & Became eligible for public pension & 74.2 & 40.3 & 77.3 & 95.3 & 78.8 & 59.8 & 76.1 & 70.5 & 51.5 \\
\hline 2. & Became eligible for private occupational pension & 1.9 & 27.5 & 0.6 & 0.6 & 0.8 & 2.2 & 0.0 & 0.0 & 1.1 \\
\hline 3. & Became eligible for a private pension & 0.2 & 5.6 & 0.2 & 0.0 & 0.4 & 0.0 & 0.0 & 0.0 & 0.6 \\
\hline & $\begin{array}{l}\text { Was offered an early retirement option/window } \\
\text { with special incentives or bonus }\end{array}$ & 9.2 & 15.6 & 3.6 & 2.0 & 2.9 & 6.2 & 7.9 & 6.0 & 18.6 \\
\hline 5. & Made redundant (for example pre-retirement) & 6.1 & 5.9 & 4.4 & 0.4 & 0.9 & 9.3 & 2.8 & 7.1 & 4.1 \\
\hline 6. & Own ill health & 6.7 & 8.9 & 10.0 & 1.3 & 9.8 & 20.9 & 13.0 & 12.0 & 20.0 \\
\hline 7. & Ill health of relative or friend & 1.1 & 2.5 & 2.7 & 0.0 & 2.0 & 0.0 & 0.9 & 1.8 & 1.7 \\
\hline 8. & To retire at same time as spouse or partner & 1.4 & 1.4 & 0.7 & 0.7 & 1.3 & 0.5 & 0.3 & 0.0 & 0.5 \\
\hline & To spend more time with family & 3.3 & 8.6 & 1.5 & 0.0 & 5.9 & 1.7 & 0.2 & 3.0 & 2.7 \\
\hline 10. & To enjoy life & 6.6 & 6.0 & 3.5 & 0.2 & 2.1 & 0.1 & 0.3 & 3.5 & 1.0 \\
\hline
\end{tabular}

Note: data in the table are weighted; respondents could select more than one answer option, i.e. the sum of the share of each reason for which the person retired exceeds $100 \%$.

\section{REFERENCES}


DRUŠ. ISTRAŽ. ZAGREB GOD. 27 (2018), BR. 4, STR. $671-690$

BAĐUN, M., SMOLIĆ, Š. PREDICTORS OF EARLY..
Bađun, M. (2017). Determinants of disability pensions in Croatia: The role of institutions. Public Sector Economics, 41(1), 109-128. https://doi. org/10.3326/pse.41.1.10

Baloković, S. (2011). Prijevremeno umirovljenje u Republici Hrvatskoj [Early retirement in the Republic of Croatia]. Revija za socijalnu politiku, 18(1), 61-76. https://doi.org/10.3935/rsp.v18i1.976

Been, J., \& Knoef, M. (2017). Job-search requirements for unemployed at the end of working life. Effects on unemployment dynamics and self-employment probabilities. Journal of Human Resources, 52(2), 491-530. https://doi.org/10.3368/jhr.52.2.0415-7063R1

Bloemen, H., Hochguertel, S., \& Zweerink, J. (2016). Gradual retirement in the Netherlands. An analysis using administrative data. Research on Aging, 38(2), 202-233. https://doi.org/10.1177/01640275155 85358

Bonsdorff, M. E., Huuhtanen, P., Tuomi, K., \& Seitsamo, J. (2010). Predictors of employees' early retirement intentions: An 11-year longitudinal study. Occupational Medicine, 60(2), 94-100. https://doi.org/ 10.1093/occmed/kqp126

Bould, S. (1980). Unemployment as a factor in early retirement decisions. The American Journal of Economics and Sociology, 39(2), 123-136. https://doi.org/10.1111/j.1536-7150.1980.tb01622.x

Börsch-Supan, A., Brandt, M., Hunkler, C., Kneip, T., Korbmacher, J., Malter, F., Schaan, B., Stuck, S., \& Zuber, S. (2013). Data resource profile: The Survey of Health, Ageing and Retirement in Europe (SHARE). International Journal of Epidemiology, 42(4), 992-1001. https://doi.org/ 10.1093/ije/dyt088

Börsch-Supan, A. (2017). Survey of health, ageing and retirement in Europe (SHARE) Wave 6. Release version: 6.0.0. SHARE-ERIC. Data set. https://dx.doi.org/10.6103/SHARE.w6.600

Carlsen, K., Oksbjerg Dalton, S., Frederiksen, K., Diderichsen, F., \& Johansen, C. (2008). Cancer and the risk for taking early retirement pension: A Danish cohort study. Scandinavian Journal of Public Health, 36(2), 117-125. https://doi.org/10.1177/1403494807085192

Dahl, S.-A., Nilsen, Ø. A., \& Vaage, K. (2003). Gender differences in early retirement behaviour. European Sociological Review, 19(2), 179-198. https://doi.org/10.1093/esr/19.2.179

Dal Bianco, C., Trevisan, E., \& Weber, G. (2015). "I want to break free": The role of working conditions on retirement expectations and decisions. European Journal of Ageing, 12(1), 17-28. https://doi.org/10.1007/ s10433-014-0326-8

Danø, A. M., Ejrnæs, M., \& Husted, L. (2005). Do single women value early retirement more than single men? Labour Economics, 12(1), 47-71. https://doi.org/10.1016/j.labeco.2004.03.002

De Luca, G., Celidoni, M., \& Trevisan, E. (2015). Item nonresponse and imputation strategy in SHARE Wave 5. In F. Malter, \& A. Börsch-Supan (Eds.), SHARE Wave 5: Innovations \& Methodology (pp. 85-100). Munich: MEA, Max Planck Institute for Social Law and Social Policy. de Wind, A., Geuskens, G. A., Reeuwijk, K. G., Westerman, M. J., Ybema, J. F., Burdorf, A., Bongers, P. M., \& van der Beek, A. J. (2013). 
DRUŠ. ISTRAŽ. ZAGREB GOD. 27 (2018), BR. 4 STR. $671-690$

BAĐUN, M., SMOLIĆ, Š. PREDICTORS OF EARLY...
Pathways through which health influences early retirement: A qualitative study. BMC Public Health, 13(292), 1-9. https://doi.org/10.1186/ 1471-2458-13-292

de Wind, A., Geuskens, G. A., Ybema, J. F, Blatter, B. M., Burdorf, A., Bongers, P. M., \& van der Beek, A. J. (2014). Health, job characteristics, skills, and social and financial factors in relation to early retirement - Results from a longitudinal study in the Netherlands. Scandinavian Journal of Work, Environment and Health, 40(2), 186-194. https://doi. org/10.5271/sjweh.3393

Dorn, D., \& Sousa-Poza, A. (2010). "Voluntary" and "involuntary" early retirement: An international analysis. Applied Economics, 42(4), 427-438, https://doi.org/10.1080/00036840701663277

Dorn, D., \& Sousa-Poza, A. (2005). The determinants of early retirement in Switzerland. Schweizerische Zeitschrift für Volkswirtschaft und Statistik, 141(2), 247-283.

Drobnič, S., Beham, B., \& Präg, P. (2010). Good job, good life? Working conditions and quality of life in Europe. Social Indicators Research, 99(2), 205-225. https://doi.org/10.1007/s11205-010-9586-7

Dwyer, D. S., \& Mitchell, O. S. (1999). Health problems as determinants of retirement: Are self-rated measures endogenous? Journal of Health Economics, 18(2), 173-193. https://doi.org/10.1016/S0167-6296(98)00034-4

Eurofound (2017). Sixth European working conditions survey - Overview report (2017 update), Publications Office of the European Union, Luxembourg. Available at https://www.eurofound.europa.eu/publications/ report/2016/working-conditions/sixth-european-working-conditionssurvey-overview-report

European Commission (2011). Eurobarometer survey active ageing. MEMO/12/10, 13 January 2011, Brussels. Available at http://europa. eu/rapid/press-release_MEMO-12-10_en.htm?locale $=$ en

European Commission (2018). Country Report Croatia 2018. 7 March 2018, Brussels. Available at https://ec.europa.eu/info/sites/info/files/ 2018-european-semester-country-report-croatia-en.pdf

Eurostat (2017). Employment and unemployment (LFS). Database. Available at http://ec.europa.eu/eurostat/web/lfs/data/database

Euwals, R., van Vuuren, D., \& Wolthoff, R. (2010). Early retirement behaviour in the Netherlands: Evidence from a policy reform. De Economist, 158(3), 209-236. https://doi.org/10.1007/s10645-010-9139-0

Fischer, J. A. V., \& Sousa-Poza, A. (2006). The institutional determinants of early retirement in Europe. University of St. Gallen Economics Discussion Paper, No. 2006-08. Available at https://papers.ssrn.com/sol3/ papers.cfm?abstract_id $=895081$

Franic, J., \& Williams, C. (2017). Illegitimate economic practices in Croatia: Findings from a representative survey of 2,000 citizens, GREY Working Paper, No. 9. https://doi.org/10.2139/ssrn.2932315

Gómez-Léon, M., \& Miret-Gamudi, P. (2014). Working after age 50 in Spain. Is the trend toward early retirement reversing? Vienna Yearbook of Population Research, 12(2014), 115-140. https://doi.org/10.1553/ populationyearbook2014s115 
DRUŠ. ISTRAŽ. ZAGREB GOD. 27 (2018), BR. 4, STR. $671-690$

BAĐUN, M., SMOLIĆ, Š.: PREDICTORS OF EARLY..
Hochman, O., \& Lewin-Epstein, N. (2013). Determinants of early retirement preferences in Europe: The role of grandparenthood. International Journal of Comparative Sociology, 54(1), 29-47. https://doi. org/10.1177/0020715213480977

HZMO (2016). Statistical information of the Croatian pension insurance institute, No. 4/2016, Zagreb: Hrvatski zavod za mirovinsko osiguranje.

Idler, E. L., \& Benyamini, Y. (1997). Self-rated health and mortality: A review of twenty-seven community studies. Journal of Health and Social Behavior, 38(1), 21-37. https://doi.org/10.2307/2955359

Jylhä, M. (2009). What is a self-rated health and why does it predict mortality? Towards a unified conceptual model. Social Science $\mathcal{E}$ Medicine, 69(3), 307-316. https://doi.org/10.1016/j.socscimed.2009.05.013

Karpansalo, M., Kauhanen, J., Lakka, T. A., Manninen, P., Kaplan, G. A., \& Salonen, J. T. (2005). Depression and early retirement: Prospective population based study in middle aged men. Journal of Epidemiology and Community Health, 59(1), 70-74. https://doi.org/10.1136/jech.2003. 010702

Kubicek, B., Korunka, C., Hoonakker, P., \& Raymo, J. M. (2010). Work and family characteristics as predictors of early retirement in married men and women. Research on Ageing, 32(4), 467-498. https://doi.org/ 10.1177/0164027510364120

Lund, T., \& Villadsen, T. (2005). Who retires early and why? Determinants of early retirement pension among Danish employees 57-62 years. European Journal of Ageing, 2(4), 275-280. https://doi.org/ 10.1007/s10433-005-0013-x

Miah, M. S., \& Wilcox-Gök, V. (2011). Do the sick retire early? Chronic illness, asset accumulation and early retirement. Applied Economics, 39(15), 1921-1936. https://doi.org/10.1080/00036840600690165

Nestić, D., \& Rašić Bakarić, I. (2008). From work to retirement: Pension system incentives to continued labour market participation in Croatia. In M. Vehovec (Ed.), New perspectives on a longer working life in Croatia and Slovenia (pp. 81-99). Zagreb: Ekonomski institut and Friedrich Ebert Stiftung.

Nestić, D., Rubil, I., \& Tomić, I. (2015). Analiza razlika u plaćama između javnog sektora, poduzeća u državnom vlasništvu i privatnog sektora u Hrvatskoj 2000.-2012. [Analysis of the difference in wages between the public sector, state-owned enterprises and the private sector in Croatia in the period 2000-2012]. Privredna kretanja i ekonomska politika, 24(1), 7-51.

Polanec, S., Ahčan, A., \& Verbič, M. (2013). Retirement decisions in transition: Microeconometric evidence from Slovenia. Post-Communist Economies, 25(1), 99-118. https://doi.org/10.1080/14631377.2013.756703

Rutkowski, J. (2007). From the shortage of jobs to the shortage of skilled workers: Labor markets in the EU new member states. Institute for the Study of Labor Discussion Paper, No. 3202. Available at http://repec.iza. org/dp3202.pdf

Schils, T. (2008). Early retirement in Germany, the Netherlands, and the United Kingdom: A longitudinal analysis of individual factors 
DRUŠ. ISTRAŽ. ZAGREB GOD. 27 (2018), BR. 4 STR. $671-690$

BAĐUN, M., SMOLIĆ, Š. PREDICTORS OF EARLY... and institutional regimes. European Sociological Review, 24(3), 315-329. https://doi.org/10.1093/esr/jcn009

Siegrist, J., Wahrendorf, M., von dem Knesebeck, O., Jürges, H., \& Börsch-Supan, A. (2007). Quality of work, well-being, and intended early retirement of older employees - Baseline results from the SHARE Study. European Journal of Public Health, 17(1), 62-68. https://doi.org/ 10.1093/eurpub/ckl084

Staubli, S., \& Zweimüller, J. (2013). Does increasing the early retirement age increase employment of older workers? Journal of Public Economics, 108(December), 17-32. https://doi.org/10.1016/j.jpubeco. 2013.09.003

Szinovacz, M. E., \& Deviney, S. (2000). Marital characteristics and retirement decisions. Research on Ageing, 22(5), 470-498. https://doi.org/ $10.1177 / 0164027500225002$

Šverko, B., \& Galić, Z. (2014). The perceived quality of working life in Croatia and the European Union. Društvena istraživanja, 23(4), 557-575. https://doi.org/10.5559/di.23.4.01

Van Bavel, J., \& De Winter, T. (2013). Becoming a grandparent and early retirement in Europe. European Sociological Review, 29(6), 1295-1308. https://doi.org/10.1093/esr/jct005

van den Berg, T. I. J., Elders, L. A. M., \& Burdorf, A. (2010). Influence of health and work on early retirement. Journal of Occupational and Environmental Medicine, 52(6), 576-583. https://doi.org/10.1097/JOM. 0b013e3181de8133

Vehovec, M. (2003). Usporedni pregled defenzivnog restrukturiranja tvrtki u Hrvatskoj i Sloveniji [Comparative review of defensive restructuring of firms in Croatia and Slovenia]. Financijska teorija $i$ praksa, 27(4), 609-623. Available at https://hrcak.srce.hr/5774

Vijan, S., Hayward, R. A., \& Langa, K. M. (2004). The impact of diabetes on workforce participation: Results from a national household sample. Health Services Journal, 39(6 Pt 1), 1653-1669. doi: https://dx. doi.org/10.1111\%2Fj.1475-6773.2004.00311.x

Vukorepa, I. (2015). Lost between sustainability and adequacy: Critical analysis of the Croatian pension system's parametric reform. Revija za socijalnu politiku, 22(3), 279-308. https://doi.org/10.3935/rsp.v22i3.1307

\section{Prediktori sklonosti ranijem umirovljenju u Hrvatskoi}

Marijana BAĐUN

Institut za javne financije, Zagreb

Šime SMOLIĆ

Ekonomski fakultet, Zagreb

U radu se koristimo bazom podataka 6. vala "Istraživanja o zdravlju, starenju i umirovljenju u Europi" (SHARE), kako bismo modelom logističke regresije ispitali prediktore ranijeg odlaska u mirovinu u Hrvatskoj. Pritom uzimamo u obzir sociodemografska, zdravstvena i financijska obilježja 
DRUŠ. ISTRAŽ. ZAGREB GOD. 27 (2018), BR. 4, STR. $671-690$

BAĐUN, M., SMOLIĆ, Š. PREDICTORS OF EARLY... zaposlenika, kao i njihovu kvalitetu života te obiliežja glavnoga posla. Rezultati našeg istraživanja upućuju na to da su ranijem umirovljenju skloniji zaposlenici koji rade u privatnom sekłoru, koji imaju nisku kvalitetu života, slabije su obrazovani ili su subjektivno lošega zdravlja. Promjene mirovinskoga sustava kojima bi ranije umirovljenje bilo manje privlačno nisu dovoljne. Mnogi bi hrvatski zaposlenici bili spremni raditi dulje kad bi imali bolje poslove,

obrazovanje i zdravlje. To su područja na kojima su u Hrvatskoi potrebna znatna poboljšanja.

Ključne riječi: ranije umirovljenje, mirovinski sustav, starenje, Hrvatska, SHARE

\section{(c) (i) (8)}

Međunarodna licenca / International License:

Imenovanje-Nekomercijalno / Attribution-NonCommercial 